Laporan Penelitian

\title{
Hubungan hasil BERA dan TEOAE dengan kadar HbA1c pada pasien Diabetes Melitus tipe-2
}

\author{
Novi Primadewi, Hadi Sudrajad, Hendra Eka Prasetya \\ Departemen Ilmu Kesehatan Telinga Hidung Tenggorok-Bedah Kepala Leher Fakultas \\ Kedokteran Universitas Sebelas Maret/ Rumah Sakit Dr. Moewardi \\ Surakarta
}

\begin{abstract}
ABSTRAK
Latar belakang: Neuropati adalah salah satu komplikasi yang paling sering dari Diabetes Melitus (DM) tipe 2. Disamping neuropati perifer dan otonom, pasien dengan DM tipe 2 juga dapat menderita gangguan pendengaran tipe sensorineural hearing loss (SNHL) pada frekuensi tinggi. Pada studi ini hubungan $\mathrm{HbA1c}$ dengan hasil pemeriksaan brainstem evoked response audiometry (BERA) dan transient evoked otoacoustic emissions (TEOAE) digunakan untuk mendeteksi neuropati akustik dan sentral pada pasien DM tipe 2. Tujuan: Untuk mengetahui hubungan kadar HbA1c pada DM tipe 2 dengan masa laten gelombang BERA dan respon TEOAE. Metode: Desain penelitian cross sectional study, dilakukan dari Maret 2018 hingga jumlah sample terpenuhi. Penelitian dimulai dengan mengidentifikasi pasien DM tipe 2 dengan profil kadar HbAlc, kemudian dilanjutkan dengan pemeriksaan TEOAE dan BERA. Hasil: Dari hasil pemeriksaan BERA terdapat hubungan signifikan antara HbA1c dengan masa laten gelombang BERA di intensitas $70 \mathrm{~dB}$ dan $80 \mathrm{~dB}$ kecuali latensi antar-puncak I-V, tetapi tidak berhubungan signifikan pada intensitas $90 \mathrm{~dB}$. Didapatkan pada pemeriksaan TEOAE di telinga kanan kadar HbA1c berhubungan dengan hasil pemeriksaan TEOAE kategori refer rata-rata 8,67 $\pm 1,14 \%$, sedangkan pasien dengan hasil pemeriksaan TEOAE kategori pass rata-rata $7,73 \pm 0,95 \%$. Hasil uji $t$ test didapatkan nilai $\mathrm{p}=0,021(\mathrm{p}<0,05)$. TEOAE di telinga kiri kategori refer rata-rata $8,82 \pm 1,09 \%$, sedangkan pasien dengan hasil pemeriksaan TEOAE kategori pass rata-rata $7,66 \pm 0,88 \%$. Hasil uji $t$ test didapatkan nilai $\mathrm{p}=0,003$ $(\mathrm{p}<0,05)$. Kesimpulan: Terdapat hubungan yang signifikan secara statistik antara kadar $\mathrm{HbA} 1 \mathrm{c}$ dengan hasil pemeriksaan gelombang BERA dan TEOAE.
\end{abstract}

Kata kunci: HbA1c, DM tipe 2, BERA, TEOAE

\begin{abstract}
Background: Neuropathy is complication of type 2 diabetes mellitus (DM). Besides peripheral and autonomic neuropathy, patients with type 2 DM may also have sensorineural hearing loss at high frequency. In this study the association of HbAlc level with the results of BERA and TEOAE tests was used to detect acoustic and central neuropathy in type 2 DM patients. Objective: To find out the relationship of HbAlc level in type 2 DM with BERA and TEOAE. Method: Research design cross sectional study, conducted from March 2018 until the number of samples fulfilled. The study began by identifying patients with type 2 DM with the HbAlc profile, followed by TEOAE and BERA examinations. Result: There was a significant relationship between $\mathrm{HbAlc}$ and the latent period of waves at the intensity of $70 \mathrm{~dB}$ and $80 \mathrm{~dB}$ except on the interpeak I-V latency, but not significantly related to the $90 \mathrm{~dB}$ intensity. Results of $T E O A E$ test in the right ear: the average levels of $H b A l c$ with refer category results on TEOAE test was $8.67 \pm 1.14 \%$, whereas patients with pass category results on TEOAE was $7.73 \pm 0.95 \%$. The result of t test value was $p=0.021 \quad(p<0.05)$. TEOAE on the left ear: average refer category $8.82 \pm 1.09 \%$, whereas patients with TEOAE examination results in the mean pass category $7.66 \pm 0.88 \%$. The result of $t$ test value was $p=0.003(p<0.05)$. Conclusion: There was a statistical significant relationship between HbAlc level and BERA and TEOAE.
\end{abstract}

Keywords: HbAlc, type 2 DM, BERA, TEOAE 
Alamat korespondensi: dr. Novi Primadewi, Sp.T.H.T.K.L(K), Msi Med. Bagian THT-KL RSUD Dr. Moewardi/Fakultas Kedokteran UNS Surakarta. Jl. Kol. Sutarto No.132 Surakarta. Email : Indrakila_73@, yahoo.com

\section{PENDAHULUAN}

Prevalensi diabetes melitus (DM) meningkat di seluruh dunia terutama di negaranegara berkembang. Penyakit ini muncul sebagai permasalahan kesehatan publik yang utama. World Health Organisation (WHO) memperkirakan bahwa terdapat 8,4 juta orang dengan diabetes di Indonesia pada tahun 2000 dan jumlah ini diperkirakan akan meningkat menjadi 21,3 juta pada tahun 2030. Diabetes berkontribusi sekitar $6 \%$ sebagai penyebab dari mortalitas keseluruhan pada populasi di Indonesia. ${ }^{1}$ Data Poliklinik Penyakit Dalam sub Endokrinologi Rumah Sakit Dr. Moewardi, Surakarta memperlihatkan kunjungan pasien DM selama bulan JanuariDesember 2016 sebanyak 1.586 pasien, dari data tersebut 197 pasien diantaranya memiliki keluhan penurunan pendengaran.

Seperti yang telah kita ketahui sebelumnya, gangguan pendengaran yang terjadi sebagai komplikasi dari DM tipe 2 bersifat sensorineural hearing loss (SNHL). Kehilangan pendengaran sensorineural seringkali didefinisikan sebagai kehilangan sensitivitas pendengaran akibat cidera jaringan perifer dan atau kematian sel pada organ pendengaran di koklea, selain itu struktur-struktur auditoris sentral dari otak dapat pula berperan secara independen dalam perkembangan SNHL. DM menyebabkan gangguan pendengaran sensorineural pada $10 \%$ dari populasi. ${ }^{2,3}$

Gangguan pendengaran sensorineural dapat diakibatkan oleh lesi koklear maupun lesi retrokoklear. Lesi retrokoklear dapat dideteksi dengan menggunakan pemeriksaan Brainstem Evoked Response Audiometry (BERA), sedangkan lesi koklear (misalnya kehilangan sel-sel rambut luar) dapat dideteksi dengan pemeriksaan Otoacoustic Emission (OAE), sebagaimana yang dilaporkan oleh beberapa studi. ${ }^{4,5}$ Pemeriksaan BERA adalah tes dengan menggunakan alat elektrofisiologis non-invasif untuk mendeteksi adanya lesi retrokoklear, oleh sebab itu pemeriksaan ini dapat sangat membantu dalam memandu klinisi dalam deteksi gangguan awal dari saraf auditoris dan fungsi batang otak. Beberapa perubahan yang dapat ditemukan pada pasien DM dengan gangguan pendengaran sensorineural dapat dideteksi dengan mengevaluasi latensi absolut gelombang I, III, V, serta masa laten antar-puncak (interpeak latencies [IPL]) I-III, III-V, dan I-V. ${ }^{5}$ Pemeriksaan transient evoked otoacoustic emission (TEOAE) dilakukan untuk menentukan status mikro-mekanik koklear, khususnya fungsi dari sel-sel rambut luar (outer hair cells (OHC)). Pemeriksaan TEOAE dilakukan menggunakan alat neuroaudio dengan stimulus klik 'non-linier' dengan durasi $80 \mu \mathrm{s}$, tingkat pengulangan $50 \mathrm{~Hz}$ dan intensitas $\sim 80 \mathrm{~dB}$. Hasilnya dipresentasikan dalam desibel sebagai rerata rentang frekuensi 1,2-3,5 kHz. Rerata amplitudo TEOAE di bawah $6 \mathrm{~dB}$ pada rentang frekuensi 1,2$3,5 \mathrm{kHz}$ dianggap sebagai emisi otoakustik yang kurang. ${ }^{6}$ Hemoglobin A1c adalah glukosa stabil yang terikat pada gugus $\mathrm{N}$-terminal pada rantai HbA0 membentuk suatu modifikasi post translasi, sehingga glukosa bersatu dengan kelompok amino bebas pada residu valin $\mathrm{N}$-terminal rantai $\beta$ haemoglobin. Eritrosit yang mengandung HbA1c akan terus-menerus terglikasi menyebabkan hiperglikemia. Keadaan hiperglikemia pada pasien diabetes akan mengalami siklus glikolisis dan pembentukan AGE produk (AGE pathway). Komite ahli dari ADA dan European Association for the Study of Diabetes (EASD) kemudian merekomendasikan penggunaan $\mathrm{HbAlc}$ untuk diagnosis diabetes melitus, dan pada tahun 2010 ADA memasukkan HbA1c ke dalam kriteria diagnosis diabetes. ${ }^{7,8}$ 
Tujuan penelitian ini dilakukan untuk mengetahui hubungan antara kadar $\mathrm{HbA1c}$ pada DM tipe 2 dengan pemanjangan masa laten gelombang BERA dan penurunan respon TE OAE.

\section{METODE}

Penelitian dilakukan di Poliklinik Rawat Jalan Telinga Hidung Tenggorok-Bedah Kepala Leher (THT-KL) sub Neurotologi Rumah Sakit Umum Daerah (RSUD) Dr. Moewardi, Surakarta dan Poliklinik Rawat Jalan Penyakit Dalam sub Endokrinologi RSUD Dr. Moewardi, Surakarta. Waktu penelitian dimulai dari bulan Maret 2018 hingga jumlah sampel terpenuhi.
Desain penelitian ini adalah cross sectional study mengenai hubungan kadar $\mathrm{HbA} 1 \mathrm{c}$ pada DM tipe 2 dengan pemanjangan masa laten gelombang BERA dan penurunan respon TEOAE. Penelitian ini dimulai dengan mengidentifikasi kelompok pasien DM tipe 2 dengan profil gula darah HbAlc dari pasien tersebut, kemudian dilanjutkan dengan pemeriksaan BERA dan TEOAE.

\section{HASIL}

Pada hubungan kadar HbAlc dengan BERA, dianalisis dengan uji korelasi Pearson jika data berdistribusi normal, dan jika data tidak berdistribusi normal, maka menggunakan uji Spearman rank. Uji normalitas dilakukan dengan uji Shapiro Wilk, hal ini dikarenakan jenis data berupa numerik-numerik.

Tabel 1. Hasil pemeriksaan respon TE OAE dan hasil BERA

\begin{tabular}{|c|c|c|c|c|}
\hline Variabel & Mean & SD & $\mathrm{F}$ & $\%$ \\
\hline Umur (Tahun) & 51,20 & 4,57 & & \\
\hline \multicolumn{5}{|l|}{ Lama DM } \\
\hline$<5$ tahun & & & 10 & $33,3 \%$ \\
\hline$\geq 5$ tahun & & & 20 & $66,7 \%$ \\
\hline HbA1c $(\%)$ & 8,20 & 1,13 & & \\
\hline \multicolumn{5}{|l|}{ TE OAE } \\
\hline Kanan (Refer) & & & 15 & $50,0 \%$ \\
\hline Kiri (Refer) & & & 14 & $46,7 \%$ \\
\hline \multicolumn{5}{|l|}{ BERA (MS) } \\
\hline 70dB I & 2,15 & 0,57 & & \\
\hline 70dB III & 4,12 & 0,36 & & \\
\hline $70 \mathrm{~dB} \mathrm{~V}$ & 6,53 & 0,41 & & \\
\hline 70dB I-III & 2,46 & 0,40 & & \\
\hline 70dB III-V & 2,14 & 0,41 & & \\
\hline 70dB I-V & 4,32 & 0,16 & & \\
\hline $80 \mathrm{~dB} I$ & 1,67 & 0,15 & & \\
\hline 80dB III & 3,89 & 0,28 & & \\
\hline $80 \mathrm{~dB} \mathrm{~V}$ & 5,86 & 0,35 & & \\
\hline 80dB I-III & 2,27 & 0,41 & & \\
\hline 80dB III-V & 1,88 & 0,21 & & \\
\hline $80 \mathrm{~dB} I-\mathrm{V}$ & 4,30 & 0,50 & & \\
\hline $90 \mathrm{~dB} I$ & 1,49 & 0,16 & & \\
\hline 90dB III & 4,04 & 0,64 & & \\
\hline $90 \mathrm{~dB}$ V & 5,54 & 0,32 & & \\
\hline 90dB I-III & 2,50 & 0,48 & & \\
\hline $90 \mathrm{~dB}$ III-V & 1,87 & 0,26 & & \\
\hline $90 \mathrm{~dB} I-V$ & 4,10 & 0,61 & & \\
\hline
\end{tabular}


Tabel 2. Hubungan HbA1c Terhadap Gelombang BERA

\begin{tabular}{|c|c|c|}
\hline \multirow{2}{*}{ Bera } & \multicolumn{2}{|c|}{ HbA1c } \\
\hline & $\mathrm{r}$ & $\mathrm{p}$ \\
\hline $70 \mathrm{~dB} I$ & 0,782 & $0,000^{*}$ \\
\hline 70dB III & 0,560 & $0,001 *$ \\
\hline $70 \mathrm{~dB}$ V & 0,451 & $0,012 *$ \\
\hline $70 \mathrm{~dB}$ I-III & 0,573 & $0,001 *$ \\
\hline $70 \mathrm{~dB}$ III-V & 0,836 & $0,000 *$ \\
\hline $70 \mathrm{~dB} I-V$ & 0,490 & $0,006^{*}$ \\
\hline $80 \mathrm{~dB} I$ & 0,878 & $0,000^{*}$ \\
\hline 80dB III & 0,401 & $0,028 *$ \\
\hline $80 \mathrm{~dB} \mathrm{~V}$ & 0,416 & $0,022 *$ \\
\hline 80dB I-III & 0,420 & $0,021 *$ \\
\hline $80 \mathrm{~dB}$ III-V & 0,537 & $0,002 *$ \\
\hline $80 \mathrm{~dB} I-V$ & $-0,034$ & 0,860 \\
\hline $90 \mathrm{~dB}$ I & 0,211 & 0,263 \\
\hline 90dB III & $-0,239$ & 0,204 \\
\hline $90 \mathrm{~dB}$ V & $-0,143$ & 0,451 \\
\hline 90dB I-III & $-0,068$ & 0,719 \\
\hline 90dB III-V & $-0,048$ & 0,803 \\
\hline $90 \mathrm{~dB} I-\mathrm{V}$ & $-0,102$ & 0,593 \\
\hline
\end{tabular}

Tabel 3. Hubungan HbA1c terhadap penurunan TEOAE pada telinga kanan

\begin{tabular}{ccccc}
\hline Variabel & OAE kanan & $\mathrm{N}$ & Mean $\pm \mathrm{SD}$ & $\mathrm{p}$ \\
\hline \multirow{2}{*}{ HbA1c } & Refer & 15 & $8,67 \pm 1,14$ & $0,021^{*}$ \\
& Pass & 15 & $7,73 \pm 0,95$ & \\
\hline
\end{tabular}

Tabel 4. Hubungan HbA1c terhadap penurunan TEOAE pada telinga kiri

\begin{tabular}{ccccc}
\hline Variabel & OAE kiri & N & Mean \pm SD & p \\
\hline HbA1c & Refer & 14 & $8,82 \pm 1,09$ & $0,003^{*}$ \\
& Pass & 16 & $7,66 \pm 0,88$ & \\
\hline
\end{tabular}

Pada hubungan kadar HbA1c dengan TEOAE, dianalisis dengan uji beda $t$ test jika data berdistribusi normal, dan jika data tidak berdistribusi normal, maka menggunakan uji Mann Whitney. Uji normalitas dilakukan dengan uji Shapiro Wilk, hal ini dikarenakan jenis data berupa numerik-nominal. Pengujian dikatakan ada hubungan yang signifikan jika nilai $p$-value $\leq 0,05$.

Penelitian ini dilakukan pada 30 pasien DM tipe 2 yang berobat di poliklinik Penyakit Dalam RSUD Dr. Moewardi, Surakarta mulai bulan Maret 2018. Penelitian ini dimulai dengan mengidentifikasi kelompok pasien DM tipe 2 dengan profil gula darah $\mathrm{HbA} 1 \mathrm{c}$ dari pasien tersebut, kemudian dilanjutkan dengan pemeriksaan TEOAE dan BERA di Poliklinik THT-KL sub Neurotologi. Berdasarkan penelitian diketahui bahwa umur pasien DM tipe 2 rata-rata $51,20 \pm 4,57$ tahun, lama menderita penyakit DM mayoritas $\geq 5$ tahun yaitu ada 20 pasien $(66,7 \%)$,

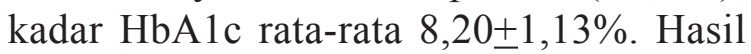
pemeriksaan respon TEOAE pada telinga kanan pasien ada 15 pasien $(50,0 \%)$ yang mengalami gangguan pendengaran (refer), dan pada telinga kiri ada 14 pasien $(46,7 \%)$ terjadi gangguan pendengaran (refer). Data selengkapnya dapat dilihat pada tabel 1 .

Berdasarkan tabel 2. pemeriksaan kadar HbA1c memiliki hubungan yang signifikan dengan hasil pengukuran BERA pada intensitas $70 \mathrm{~dB}$, dan $80 \mathrm{~dB}$, dimana pada intensitas $70 \mathrm{~dB}$ kadar HbA1c berhubungan positif dan signifikan dengan latensi absolut dari gelombang I, III, V, dan latensi inter-puncak I-III, III-V, I-V, sedangkan pada intensitas 80 $\mathrm{dB}$ berhubungan positif dan signifikan dengan 
latensi absolut dari gelombang I, III, V, dan latensi antar-puncak I-III, dan III-V yaitu dengan nilai $\mathrm{p}<0,05$, dimana semakin tinggi kadar HbAlc, maka semakin memanjang masa laten gelombang pada pemeriksaan BERA. Sedangkan pemeriksaan kadar HbAlc tidak berhubungan signifikan dengan masa laten gelombang BERA pada intensitas $80 \mathrm{~dB}$ dengan latensi inter-puncak I-V dan intensitas $90 \mathrm{~dB}$ dengan latensi absolut dari gelombang I, III, V, dan latensi inter-puncak I-III, III-V dan I-V dengan nilai $\mathrm{p}>0,05$.

Berdasarkan tabel 3. Hasil pemeriksaan kadar HbA1c dengan hasil pemeriksaan TEOAE kategori refer rata-rata 8,67 $\pm 1,14 \%$, sedangkan pasien dengan hasil pemeriksaan TEOAE kategori pass rata-rata 7,73 $\pm 0,95 \%$. Hasil uji $t$ test didapatkan nilai $\mathrm{p}=0,021$ $(\mathrm{p}<0,05)$ yang berarti bahwa terdapat perbedaan yang signifikan hasil pemeriksaan kadar HbAlc pada hasil pemeriksaan TEOAE kategori pass dengan refer, atau dapat dikatakan hasil pemeriksaan kadar HbA1c berhubungan signifikan dengan hasil pemeriksaan TEOAE pada telinga kanan.

Berdasarkan tabel 4. Hasil pemeriksaan kadar HbA1c dengan hasil pemeriksaan TEOAE kategori refer rata-rata $8,82 \pm 1,09 \%$, sedangkan pasien dengan hasil pemeriksaan TEOAE kategori pass rata-rata 7,66 $\pm 0,88 \%$. Hasil uji $t$ test didapatkan nilai $\mathrm{p}=0,003$ $(p<0,05)$ yang berarti bahwa terdapat perbedaan yang signifikan hasil pemeriksaan kadar HbAlc pada hasil pemeriksaan TEOAE kategori pass dengan refer, atau dapat dikatakan hasil pemeriksaan kadar $\mathrm{HbA} 1 \mathrm{c}$ berhubungan signifikan dengan hasil pemeriksaan TEOAE pada telinga kiri.

\section{DISKUSI}

Neuropati diabetik sentral adalah sebuah konsep baru dan dapat dideteksi dengan metode sederhana non-invasif. Salah satu dari metode ini adalah TEOAE dan BERA. Dengan menggunakan metode ini, patologi fungsional dan otonom dari saraf akustik hingga bagian atas dari batang otak dapat di identifikasi pada tahap-tahap awal. Lesi-lesi pada tingkat ini menghasilkan perubahan pada amplitudo dan latensi BERA. Evaluasi dari perubahan-perubahan ini dapat membantu menentukan disfungsi neurologis subklinis awal dari DM. ${ }^{9}$ Pada penelitian ini kadar HbA1c berhubungan signifikan dengan hasil pemeriksaan TEOAE pada telinga kanan demikian juga pada telinga kiri. Hal ini menunjukkan pasien dengan kontrol glikemik yang lebih buruk akan menyebabkan penurunan respon TEOAE, tetapi ini masih dipengaruhi oleh telah berapa lama pasien tersebut menderita diabetes. Pada beberapa penelitian menyebutkan mikroangiopati bertanggung jawab akan neuropati diabetik, dimana hal tersebut menjelaskan insidens yang lebih tinggi dari evoked response batang otak pada pasien dengan lama menderita penyakit lebih dari 6-7 tahun. ${ }^{5}$ Pada penelitian

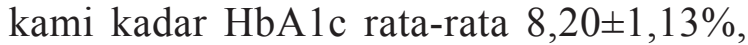
menunjukkan bahwa kontrol glikemik yang buruk masih lebih dominan sebagai penyebab menurunnya respon TEOAE.

Studi histopatologi menunjukkan adanya kerusakan pada saraf dan pembuluh darah di membran basilaris dan striae vaskularis, yang terbukti lebih tebal pada penderita DM. Selain penebalan pembuluh darah, striae vaskularis yang atrofi dan hilangnya sel rambut luar dapat mengakibatkan adanya gangguan transduksi dan transmisi signal dan hal inilah kemudian yang terdeteksi berupa penurunan respon TEOAE yang kemudian bermanifestasi klinis berupa gangguan pendengaran. ${ }^{10-12}$ Adanya hubungan yang signifikan antara kendali glikemik dengan gangguan pendengaran dilaporkan pada 4 hasil penelitian, sedangkan hasil yang tidak signifikan dilaporkan pada 2 penelitian lainnya. ${ }^{13}$ Peneliti menemukan bahwa latensi absolut gelombang I, III, V, dan latensi interpuncak I-III, III-V, I-V, pada intensitas $70 \mathrm{~dB}$ dan latensi absolut gelombang I, III, V, dan latensi inter-puncak I-III, III-V pada intensitas 
$80 \mathrm{~dB}$ berhubungan positif dan signifikan dengan nilai $\mathrm{p}<0,05$ dimana semakin tinggi kadar HbA1c, maka semakin memanjang masa laten gelombang pada pemeriksaan BERA. Sedangkan pemeriksaan kadar HbA1c tidak berhubungan signifikan dengan masa laten gelombang BERA pada intensitas $80 \mathrm{~dB}$ dengan latensi inter-puncak I-V dan intensitas $90 \mathrm{~dB}$ dengan latensi absolut dari gelombang I, III, V, dan latensi inter-puncak I-III, III-V dan I-V dengan nilai $\mathrm{p}>0,05$.

Latensi pada gelombang I di intensitas $70 \mathrm{~dB}$ dan $80 \mathrm{~dB}$ memanjang, hal ini menunjukkan bahwa transmisi n. VIII hingga tingkat nukleus koklear terganggu. Masa laten gelombang III dan V, latensi antar-puncak I-III, III-V, dan I-V pada intensitas $70 \mathrm{~dB}$ dan $80 \mathrm{~dB}$ memanjang kecuali latensi antarpuncak I-V pada intensitas $80 \mathrm{~dB}$, hal ini menunjukkan transmisi yang tertunda dari jalur auditoris pada tingkat batang otak dan mesensefalon yang mengindikasikan keadaan patologi pada tingkat-tingkat tersebut. Adapun masa laten gelombang I, III, V, interlatensi I-III, III-V, \& I-V di intensitas $90 \mathrm{~dB}$ tidak memanjang, hal ini dapat terjadi karena proses demielinisasi jalur auditoris pada tingkat batang otak dan mesensefalon di komponen gelombang tersebut belum terjadi, tetapi bila tidak disertai kontrol glikemik yang baik, maka jalur auditoris tersebut pada akhirnya juga akan mengalami proses demielinisasi. Penemuan serupa dengan hal ini telah dilaporkan sebelumnya. ${ }^{9}$ Beberapa studi serupa menunjukkan abnormalitas degeneratif pada jaringan otak dan atrofi ganglion spiral di koklea pada pasien DM, sehingga menunjukkan keberadaan neuropati sentral. Berdasarkan penemuan histologis, mereka menyimpulkan bahwa mikroangiopati pada stria vaskularis adalah faktor kausatif utama yang mengarah pada neuropati sentral di pasien DM. Siddiqi, ${ }^{14}$ telah menyadari bahwa pada pasien DM tipe 2, ganglia spiralis dalam bagian tengah maupun basal dari koklea cenderung atrofi sepanjang demielinisasi dari n. VIII.
Abnormalitas evoked response batang otak dan abnormalitas BERA umum ditemukan pada pasien dengan durasi penyakit lebih dari lima tahun dibandingkan pasien dengan durasi penyakit kurang dari lima tahun. Hal ini sesuai dengan penelitian kami dimana lama menderita penyakit DM mayoritas $\geq 5$ tahun yaitu ada 20 pasien $(66,7 \%)$ dan berhubungan signifikan. Saini et al. ${ }^{10}$ dan Papatheodorou et al. ${ }^{15}$ menyatakan bahwa mikroangiopati bertanggungjawab akan neuropati diabetik, dimana hal tersebut adalah komplikasi jangka panjang diabetes, serta hal tersebut menjelaskan insidens yang lebih tinggi dari evoked response batang otak pada pasien dengan durasi penyakit $\geq 5$ tahun. Keterlibatan difus dari regio periventrikuler, batang otak, dan korda spinalis bertanggungjawab untuk menyebabkan perlambatan waktu transmisi sentral pada pasien-pasien diabetes, selain itu kondisi ini dapat dijelaskan akibat iskemia subklinis, dimana hal tersebut dapat terjadi selama proses diabetes seperti aterosklerosis dan akumulasi sorbitol.

Pada penelitian ini didapati hubungan yang signifikan antara kadar HbAlc pada DM tipe 2 dengan masa laten gelombang BERA. Didapati juga hubungan yang signifikan antara kadar HbA1c pada DM tipe 2 dengan respon TEOAE.

\section{DAFTAR PUSTAKA}

1. World Health Organization. Global Report On Diabetes. France: WHO Press. 2016.

2. Duthey B, Kaplan W, Wirtz VJ, MantelTeeuwisse AM, Stolk P, Laing R. Priority Medicines for Europe and The World 2013 Update. Geneva: WHO. p155-7.

3. Ouda, L., Profant, O., and Syka, J. Agerelated changes in the central auditory system. Cell Tissue Res. 2015. 1:7-14.

4. Konrad-Martin D, Austin DF, Griest S, McMillan GP, McDermott D, Fausti S. Diabetes-related changes in auditory brainstem responses. Laryngoscope. 2010. 120(1):150-8. 
5. Sushil MI, Muneshwar JN, Afroz S . To Study Brain Stem Auditory Evoked Potential in Patients with Type 2 Diabetes Mellitus-A cross-sectional comparative study. Journal of Clinical and Diagnostic Research. 2016. Vol-10(11):CC01-CC04.

6. Meena R, Sonkhya D, Sonkhya N. Evaluation of hearing loss in patients with type 2 diabetes mellitus. International Journal of Research in Medical Sciences. 2016. 2281-7.

7. Edwards JL, Vincent A, Cheng T, Feldman EL. Diabetic Neuropathy: Mechanisms to Management. Pharmacol Ther. 2008. 120(1):1-34.

8. Nitin S. HbAlc and factors other than diabetes melitus affecting it. Singapore Med J. 2010. 51:616-22.

9. Sharma A, Despande AA, Brid SV. Comparative Study of Brainstem Evoked Response Audiometry in Diabetic and Nondiabetic Subjects. Sch J App Med Sci. 2016. 4(8C):2950-6.

10. Saini S, Saini R, Aseri Y, Singh BK, Verma PC. Sensorineural hearing loss in diabetic patients.Indian Journal of Basic and Applied Medical Research. 2014. 3(3): $170-4$
11. Wong ACY, Ryan AF. Mechanisms of sensorineural cell damage, death and survivalin the cochlea. Front Aging Neurosci. 2015. 3(7):58.

12. Powers AC. Diabetes Mellitus: Diagnosis, Classification and Pathophysiology. In: Kasper D, Fauci A, Hauser S, Longo D, Jameson J, Loscalzo J. Eds:Harrison's Principles of Internal Medicine, 19e. New York: McGraw-Hill. 2015.

13. Eren E, Harman E, Arsalong S, Onal K. Effects of type 2 diabetes on otoacoustic emissions and the medial olivocochlear reflex. Otolaryngol head neck surg. 2014. 150(6):1033-9.

14. Siddiqi SS, Gupta R, Aslam M, Hasan SA, Khan SA. Type-2 diabetes mellitus and auditory brainstem response. Indian Journal of Endocrinology and Metabolism.2013. 17(6):1073-7

15. Papatheodorou K, Papanas N, Banach M, Papazoglou D, Edmonds M. Complications of Diabetes. Journ Diab Res. 2016. 10(11):55. 